\title{
Discussions on Local Music Culture Inheritance in Music Education
}

\author{
Ying Chen, Yan Meng \\ Leshan Normal University, Leshan, Sichuan Province, China
}

Keywords: musical education, local music, music culture, heritage

\begin{abstract}
Local music culture is an important part of Chinese culture, carrying long-term cultural connotation. Whether it is a simple and beautiful folk song, or colorful and pleasant folk instruments, they are handed down from generation to generation. School music education is an important way for the inheritance of local music culture. The two are mutually reinforcing relations. This paper analyzes the relationship between local musical culture inheritance and school music education in detail, explores the integration of cultural ideas with music resources, and ultimately makes the local musical cultural heritage and school music education reach the reunification.
\end{abstract}

\section{Introduction}

Local music and culture is the shining essence of the five thousand years of history and culture of the Chinese nation. It is also a symbol of the spiritual civilization of the Chinese nation. However, as Western music culture continues to gain popularity, young people's awareness of local music gradually diminishes and may even disappear in the near future [1]. Local music culture is derived from the art of living, and the school is a cradle of dissemination of culture. While moderately introducing western culture, school education should also carry on lasting inheritance of our local indigenous music culture.

National music culture is a brilliant essence of the five thousand years of history and culture of the Chinese nation. It is also a symbol of the spiritual civilization of the Chinese nation. However, as Western music culture continues to gain popularity, young people's awareness of ethnic music gradually diminishes and may even disappear in the near future [1]. The national music culture is derived from the art of life, while the school is the cradle of dissemination of culture. While introducing proper western culture, school education should carry on the lasting inheritance of the national music culture in our country.

\section{The crisis of local music}

With the rapid development of economy, great changes and impacts of the changes of the times, modes of production, lifestyles, modern civilization and ideology, the living space of folk songs in our country has been encroached or squeezed, resulting in fewer and fewer people singing folk songs Many young people in ethnic minority areas are keen on urban pop music, and many folk songs are in danger of disappearing at any time. The diversified, weird, playful and dynamic pop music of the music is in line with the fast-paced life melody of the present generation [1]. A small number of local music is increasingly being excluded. Some young people, especially after 90 , still do not know what a minority of local music is.

According to the questionnaire survey conducted by universities in China, the popularity of Chinese local music is that popular songs are $55 \%$ of popular songs, $9 \%$ of art songs, $20 \%$ of children's songs, only $10 \%$ of national songs, other songs $6 \%$. There is also a set of data: students like the degree of various music survey: popular music accounted for $66 \%$, art music accounted for $11 \%$; national instrumental music only $12 \%$, foreign instrument $9 \%$, other $5 \%$ [2]. These two sets of data show that students generally do not like local music, but the pursuit of popular music.

Now, popular songs, vulgar style of Internet songs are a serious blow to the entire community, the entire nation. Many students now do not understand what local music is, but these popular Internet songs are particularly respected. Often, they do not realize that these songs have caused many 
negative effects on their own physical and mental health and have always influenced the values, outlook on life and worldview of our generation! However, to promote and inherit the national culture, especially the local music culture is for us to complete.

The current crisis and difficulties of local music are as follows: the folk songs are less and less sung, the folk instrumental traditions are lacking, the local opera responses are indifferent, and the traditional rap effect is not good [2]. Even if it is a source of pride that produces a certain kind of music (drama), it is hard to have a mesmerizing follower, not to mention the conflict and refusal to enjoy the mentality due to the differences in language and aesthetic taste It's

The function of music folk diminishes with the development of the modernization process, and the local music also changes with the change of the dependent soil. This change is manifested in the variation of cultural heritage, that is, the crisis facing local music.

\section{The relationship between local musical cultural heritage and music education}

In the course of music and culture education, how to make the local music culture better inherited has always been the focus of education and music circles. Many educators and music workers have made some efforts. At present, strengthening the emphasis on local music culture in school education is now a more arduous task. Especially nowadays, to strengthen national indigenous music and culture education has become the development trend of music and culture education in various countries.

\subsection{Local music culture as the basis for school music education resources}

Contemporary school music education is based on the excellent music culture at all times and in all countries as the overall education content. Most people focus on musical techniques, and these people find it hard to truly understand the connotation of local music culture. However, what type of music should be used as the basis of education in school music education has always been a problem to be solved in the process of music education. As an effective way to inherit the local music culture, school education should regard local music as the foundation of music and culture resources and accurately pass on the essence of the local music culture. From many aspects to comprehend the content of local music and culture, local culture cannot ignore the cultural charm and the significance of the times, but simply stay at the level of music skills [2].

\subsection{School music education as an important way to inherit the local music culture}

In the process of the inheritance of local music culture, what kind of form should be used as a carrier is also a hot spot that the music education community has long been paying attention to. Even though musicians made painstaking efforts in the inheritance of local musical culture, they also made corresponding achievements. However, in modern society, school education is the basic way for all kinds of cultural transmission and inheritance. As the cradle of cultural transmission schools, is not the fundamental way of local music and cultural heritage. On the other hand, when a lot of local music and culture are not given enough attention, the local music and cultural heritage are basically based on the study and promotion of folk music organizations. However, school education only serves as a secondary way to lead to local music the loss of some components of culture. Therefore, any cultural transmission and cultural heritage cannot ignore the fundamental way of schooling. The complete inheritance of local musical culture is the historical integration of local music, the significance of cultural representations and the representativeness of musical techniques. It is impossible for any one of them to be lost. Only when the school music education can become an important way for the local music culture heritage can we carry on the complete inheritance of the local music culture [3].

\section{The countermeasures of effectively inheriting the local music culture in music education}

For decades, experts and scholars have always had different arguments in the direction of "how ethnic music should develop and what ethnic music should take." Some experts said that "the main body of Chinese music should be rebuilt in the fundamental spirit of western music." Others believe 
that "maintaining the traditional form of music and denying or rectifying the path of Chinese music towards Westernization". Facts have proved that it is only by inheriting the fine traditions of national music, being compatible with each other, and drawing on and absorbing the formal techniques of foreign music, can the national music embark on a path of rejuvenation and development [3]. When we inherit the tradition of ethnic music, we absolutely cannot adopt a rigid attitude. Since ancient times, the national music in China has developed from the integration and variation. The instruments used by Chinese folk music such as the violin, the pipa and the suona come from the Western Regions. The complete integration of these ethnic minorities and Han music has become an integral and integral part of the Chinese national music.

In the diverse and complex contemporary music education culture, we want music education in schools to regard local music culture as basic resources. Educators and musicians should make every effort to break through the current situation and strive to develop new strategies that can be adapted to contemporary school education [4]. The local music culture is a complete heritage, to protect the integrity of local culture.

\subsection{Strengthen the importance of local music in the curriculum}

In order to cultivate professional talents in school education, in recent years one after another professional researches in local music have been set up in colleges and universities. Colleges and universities have found their shortcomings and shortcomings by comparing the number of their own local music courses and the level of scientific research. Keep its own advantages while strengthening its strengths and avoiding weaknesses to improve its work and stimulate continuous improvement and development of the minority local music teaching system [4].

For the majority of non-music students, arranging a certain music course is an effective way to improve the overall quality of students. Through the establishment of a few local music courses, students' understanding of the history and current situation of ethnic minorities is enhanced, their sense of identity with ethnic minorities is raised, their musical appreciation is enhanced, and the popularity and field of minority local music are greatly increased.

\subsection{Diversification of music teaching methods}

Colleges and universities should organize relevant professionals, strengthen the theoretical study of a few local music, and transform the past relevant music materials into a few local music material libraries, which is conducive to the setting of a few local music courses and diversifying teaching methods and methods.

Local music differs according to ethnic, geographical and linguistic differences, which requires teachers to seriously study and discuss in the practice of vocal music [5]. They should not simply follow the standardization of technical and routine singing standards, but should follow the original sound characteristics of a few indigenous music and Singing style, to achieve a flexible and diverse teaching methods and methods.

In the teaching of public music in colleges and universities, due to the strong comprehension of undergraduates, an important part of the university music course is to improve students' ability to appreciate music [4]. Class teacher boring preaching is often one of the important reasons students are tired of class. Most of the time in class should be left to students to enjoy, create and perform, so that students take the initiative to participate in teaching.

\subsection{Strengthen the popularization and popularization of local music}

Dissemination of local music through media and cultural activities is a very good channel for government, community and school. In recent years, universities have been advocating the use of local music and regional music in the selection of teaching materials as much as possible in the research of music teaching. In the method of organizing music teaching activities, the modern music teaching method is advocated in combination with the traditional music teaching method [5]. In the competitions, we should pay attention to spreading excellent local music in our country and using musical instruments with national characteristics, so as to give students more chances of approaching local music and create an atmosphere conducive to local music. 


\subsection{Pay attention to resource utilization and development}

Indiscriminate music teaching teachers, and universities should pay attention to the training of local music teachers, a selective arrangement of music teachers to conduct professional study and research, the establishment of sufficient faculty [6]. In addition, to provide good teaching of music lessons and to enable students to fully understand and feel the meaning of local music, hardware facilities are essential for teaching.

\subsection{Establish an accurate concept of local music and culture}

Chinese local music culture comes from people's living soil, with rich local flavor and ancient culture. Musical culture is agile, with changes over time. However, this cannot regard the original music culture as a decadent idea, but regards the later music culture as a flashy one. This is due to the different moods people perceive in different times, but the soul of local music culture has not changed. Establishing an accurate cultural concept is the basic condition for the complete succession of local music culture. The school music education should analyze and compare the original state of local music with the cultural status of each era, and properly grasp the teaching scale of "transforming the soul into the soul" of the local music culture [6]. Only if civil society organizations get some more professional guidance can we effectively carry on the local music culture without distortion. Only the combination of ancient and modern philosophy in school music education can open up a new path for the inheritance of local musical culture.

\subsection{Local music teaching materials to optimize schooling}

Teaching materials are the key to the school music education. The local music culture is directly demonstrated from the teaching materials. The quality of teaching materials and school education can play a decisive role in whether or not the local music culture can be completely transmitted. Complete and comprehensive teaching materials will help the heritage of local music and culture. Chinese local music culture has the characteristics of distant, rich, endless charm. Therefore, the school music education textbooks must be done to fully tap the cultural essence of the local music culture and cultural connotation, combined with the creative thinking of music education workers; we can carry on the long-term heritage of our local music and culture [7]. Local music culture is unique local characteristics, we can all regions of our country classical culture into the selective teaching materials, and then the theory of local music in our country combined with the integration of cultural resources for students to more fully inherit and promote our country's unique local music culture. In the meantime, in the education system of local music culture, we should set more courses that can be solidly based on theory to improve the theoretical system of local music.

Teaching materials are indeed an important part of school music education. However, the teaching facilities and methods of local music culture play a crucial role in diversification. More and more teaching methods in the information age, the school music education should make full use of multi-media teaching, combined with cutting-edge teaching materials and musical instruments combined with three-dimensional teaching of illustration, sound, speaking, coexistence, etc. Help stimulate students' interest in local music learning.

\subsection{Strengthen the construction of teaching staff in school music education}

At present, there are still a lot of rooms for improvement of the music education system in all the major institutions of higher education in China. Primary and secondary school music teachers trained from this point are still lacking in the quality of local music culture and cannot comprehend the essence of traditional music culture. Instead, they are more inclined to Western music, which leads music teachers to impart knowledge to students Will tend to Western music, the ability to teach our local music culture is not enough. Therefore, the educational institutions of major universities in our country should be renovated. Local musical culture should be regarded as a major specialty in major normal universities and colleges, providing future educational stars with more platforms and opportunities for learning local music and culture [7]. 


\section{Conclusions}

The Chinese nation has 5,000 years of civilization and history. The local music culture is just like the Yellow River. For years, it has been constantly flowing and spreading. In the 21st century with diversified music culture, we must strive for innovation and fundamentally change the shortcomings in the traditional music education in schools so as to truly seek the equal status of local music culture in school education. We should effectively integrate local music culture with school music education and complement each other on the basis of each other. Increase efforts to promote local music culture and the protection of national cultural heritage efforts to retain the connotation of local music culture. At the same time, it is even more necessary for the majority of musicians and educators to seek truth from facts explore new innovations and make joint efforts to fully inherit the essence and soul of local musical culture.

\section{References}

[1] S.T. Lin, School music education on the study of folk music heritage, Drama house, 2013, vol.11, pp.12-14.

[2] G.Y. Feng, Local music and cultural heritage and school music education, Chinese music, 2003, vol.1, pp.17-19.

[3] L. Zh. Fan, School Music Education and the Inheritance of Local Music Culture, Journal of Northwest University, 2005, vol.6, pp. 33-35.

[4] Q.S. Mao, Local music and cultural heritage and school music education analysis, Popular literature and art, 2012, vol.15, pp. 10-14.

[5] Y.P. Xiong, On the local music and cultural heritage and the development of school music education, Literature and art, 2011, vol.5, pp. 43-46.

[6] X.Y. Zheng, Local music and cultural heritage and school music education, Music space, 2012, vol.12, pp. 55-57.

[7] L.Q. Zhou, On music education and local musical cultural heritage, Northern Music, 2014, vol.10, pp. 19-22. 